\title{
Monitoring the three-dimensional distribution of endogenous species in the lungs by matrix-assisted laser desorption/ionization mass spectrometry imaging
}

Citation for published version (APA):

Flinders, B., Morrell, J., Marshall, P. S., Ranshaw, L. E., Heeren, R. M. A., \& Clench, M. R. (2021). Monitoring the three-dimensional distribution of endogenous species in the lungs by matrix-assisted laser desorption/ionization mass spectrometry imaging. Rapid Communications in Mass Spectrometry, 35(1), [8957]. https://doi.org/10.1002/rcm.8957

Document status and date:

Published: 15/01/2021

DOI:

$10.1002 / \mathrm{rcm} .8957$

Document Version:

Publisher's PDF, also known as Version of record

Document license:

Taverne

Please check the document version of this publication:

- A submitted manuscript is the version of the article upon submission and before peer-review. There can be important differences between the submitted version and the official published version of record. People interested in the research are advised to contact the author for the final version of the publication, or visit the $\mathrm{DOI}$ to the publisher's website.

- The final author version and the galley proof are versions of the publication after peer review.

- The final published version features the final layout of the paper including the volume, issue and page numbers.

Link to publication

\footnotetext{
General rights rights.

- You may freely distribute the URL identifying the publication in the public portal. please follow below link for the End User Agreement:

www.umlib.nl/taverne-license

Take down policy

If you believe that this document breaches copyright please contact us at:

repository@maastrichtuniversity.nl

providing details and we will investigate your claim.
}

Copyright and moral rights for the publications made accessible in the public portal are retained by the authors and/or other copyright owners and it is a condition of accessing publications that users recognise and abide by the legal requirements associated with these

- Users may download and print one copy of any publication from the public portal for the purpose of private study or research.

- You may not further distribute the material or use it for any profit-making activity or commercial gain

If the publication is distributed under the terms of Article $25 \mathrm{fa}$ of the Dutch Copyright Act, indicated by the "Taverne" license above, 


\title{
Monitoring the three-dimensional distribution of endogenous species in the lungs by matrix-assisted laser desorption/ionization mass spectrometry imaging
}

\author{
Bryn Flinders $^{1,4,2}$ | Josie Morrell ${ }^{3}$ | Peter S. Marshall ${ }^{3}$ | Lisa E. Ranshaw ${ }^{3}$ | \\ Ron M.A. Heeren ${ }^{4}$ () | Malcolm R. Clench ${ }^{1}$ (])
}

${ }^{1}$ Centre for Mass Spectrometry Imaging, Biomedical Research Centre, City Campus, Sheffield Hallam University, Sheffield, S1 1WB, UK

${ }^{2}$ Hair Diagnostix, Dutch Screening Group, Gaetano Martinolaan 63A, Maastricht, 6229 GS, The Netherlands

${ }^{3}$ GlaxoSmithKline, Gunnels Wood Road, Stevenage, SG1 2NY, UK

${ }^{4}$ Maastricht Multimodal Molecular Imaging Institute (M4I), Maastricht University,

Universiteitssingel 50, Maastricht, 6229 ER,

The Netherlands

\section{Correspondence}

M. R. Clench, Centre for Mass Spectrometry Imaging, Biomedical Research Centre, City Campus, Sheffield Hallam University, Sheffield S1 1WB, UK.

Email:m.r.clench@shu.ac.uk

Funding information

Medical Research Council
Rationale: Matrix-assisted laser desorption/ionization mass spectrometry imaging (MALDI-MSI) is routinely employed to monitor the distribution of compounds in tissue sections and generate two-dimensional (2D) images. Whilst informative the images do not represent the distribution of the analyte of interest through the entire organ. The generation of $3 \mathrm{D}$ images is an exciting field that can provide a deeper view of the analyte of interest throughout an entire organ.

Methods: Serial sections of mouse and rat lung tissue were obtained at $120 \mu \mathrm{m}$ depth intervals and imaged individually. Homogenate registration markers were incorporated in order to aid the final 3D image construction. Using freely available software packages, the images were stacked together to generate a 3D image that showed the distribution of endogenous species throughout the lungs.

Results: Preliminary tests were performed on 16 serial tissue sections of mouse lungs. A 3D model showing the distribution of phosphocholine at $\mathrm{m} / \mathrm{z} 184.09$ was constructed, which defined the external structure of the lungs and trachea. Later, a second experiment was performed using 24 serial tissue sections of the left lung of a rat. Two molecular markers, identified as $[\mathrm{PC}(32: 1)+\mathrm{K}]^{+}$at $\mathrm{m} / \mathrm{z} \quad 770.51$ and $[\mathrm{PC}(36: 4)+\mathrm{K}]^{+}$at $\mathrm{m} / \mathrm{z} 820.52$, were used to generate $3 \mathrm{D}$ models of the parenchyma and airways, respectively.

Conclusions: A straightforward method to generate 3D MALDI-MS images of selected molecules in lung tissue has been presented. Using freely available imaging software, the 3D distributions of molecules related to different anatomical features were determined.

\section{1 | INTRODUCTION}

Imaging techniques such as computed tomography (CT), magnetic resonance imaging (MRI) and positron emission tomography (PET) are commonplace in modern medicine, where they are routinely used to provide anatomical information for the diagnosis of diseases such as cancer. $^{1}$ These techniques are capable of non-invasive threedimensional (3D) imaging by generating several two-dimensional (2D) images of an organ which are rendered into a 3D model.
Combinations of these techniques such as CT-PET or MRI-PET can be used to provide more information by viewing the data from different modalities together in a 3D model. ${ }^{2}$ However, these techniques are targeted and therefore provide limited molecular information.

Matrix-assisted laser desorption/ionization mass spectrometry imaging (MALDI-MSI) has been extensively used to generate 2D images showing the distribution of drugs, lipids, peptides and proteins in tissue sections. However, this does not necessarily represent the distribution of a molecule throughout the entire organ. Expanding this 
technique with the addition of a third dimension would enable a detailed, volumetric visualization of these analytes in an entire organ and could bridge the gap between molecular and medical imaging techniques.

There are currently two approaches used to generate 3D images with mass spectrometry imaging (MSI): depth-profiling and serialsectioning. In the depth-profiling approach, ablation of the sample surface is performed exposing lower layers for analysis. This approach has been reported using secondary ion mass spectrometry (SIMS) to generate $3 D$ images of single cells by monitoring the distribution of two endogenous species (adenine and phosphocholine) allowing the nucleus and cell membrane, respectively, to be visualized. ${ }^{3}$ Laser ablation electrospray ionization (LAESI) is also capable of this type of analysis and has been used to visualize various metabolites in the leaves of a zebra plant. $^{4}$

In order to visualize the distribution of molecules throughout an entire organ the serial-sectioning approach is used. In this approach, the sample is cut into serial sections and each section is imaged and then combined into a 3D model. This methodology has primarily been reported using matrix-assisted laser desorption/ionization (MALDI); the first report visualized the distribution of the myelin basic protein (MBP) in the corpus callosum of a mouse brain. The sample was sectioned into a total of 264 tissue sections from which 10 sections were selected at equal intervals and analyzed by MALDI-MSI. Optical images of all the sections were then used to create a 3D volume of the corpus callosum; the MALDI-MS images were then rendered into the $3 \mathrm{D}$ volume. ${ }^{5}$

Mouse or rat brains are the most commonly used specimens to visualize due to their size and the availability of anatomical/histological references, which can be used to co-register with the MALDI-MS images. Later examples monitored the 3D distribution of peptides and proteins in the substantia nigra and interpeduncular nucleus. ${ }^{6}$ Proteins have also been visualized in a mouse brain tumor which were co-registered with MRI data, ${ }^{7}$ as were lipids associated with traumatic brain injury ${ }^{8}$ and recently lipids in medulloblastoma metastasis. ${ }^{9}$ The 3D distribution of peptides and lipids has even been visualized in a crab brain. ${ }^{10}$ Ambient ionization techniques such as desorption electrospray ionization mass spectrometry imaging (DESI-MSI) have also been used to investigate the 3D distribution of lipids that make up the white and grey matter in mouse brain. ${ }^{11} 3 \mathrm{D}$ imaging has also been shown to be a useful technique to help better understand the molecular make-up of tumor tissue and to better define the boundaries between the different tissue types. ${ }^{12,13}$ This is required because of the heterogeneous nature of tumor tissue, which cannot be accurately represented in a single tissue section. The quantitative $3 D$ imaging of chemotherapeutic agents in tumor tissue has also been demonstrated. ${ }^{14}$

As the previous examples demonstrate, 3D imaging with MSI is becoming more widely applied due to its ability to help with complex tissues and to better understand diseases. This widespread application is also being facilitated by the development of faster commercial instruments and software. ${ }^{15,16}$
The aim of the work reported here is to develop methodology to monitor the 3D distribution of endogenous species throughout the lungs using MALDI-MSI. Serial sections were obtained at $120 \mu \mathrm{m}$ depth intervals through the control mouse lung tissue and imaged individually, and homogenate registration markers were incorporated in order to aid the final 3D image construction using freely available software.

\section{2 | EXPERIMENTAL}

\section{1 | Information}

Healthy mouse lung tissue was obtained from a control batch of tissue; however, the strain could not be verified. All animal studies were ethically reviewed and carried out in accordance with the UK Animals (Scientific Procedures) Act 1986, European Directive 2010/63/EU and the GSK Policy on the Care, Welfare and Treatment of Laboratory Animals. Healthy rat lung tissue (Wistar Han) was obtained from a control group of rats sacrificed for a study on colonic anastomotic healing. The experimental protocol complied with the Dutch Animal Experimental Act and was approved by the Animal Experimental Committee of Maastricht University Medical Centre (DEC number 2014-120).

\subsection{Materials}

$\alpha$-Cyano-4-hydroxycinnamic acid (CHCA), gelatin from porcine skin (type B) and trifluoroacetic acid (TFA) were purchased from SigmaAldrich (Gillingham, UK). Methanol (MeOH) was purchased from Fisher Scientific (Loughborough, UK). Norharmane (NOR) and chloroform $\left(\mathrm{CHCl}_{3}\right)$ were purchased from Sigma-Aldrich (Zwijndrecht, The Netherlands). Methanol, xylene and ethanol (EtOH) were purchased from Biosolve (Valkenswaard, The Netherlands). Hematoxylin and eosin $Y$ were purchased from Merck (Darmstadt, Germany) and J.T. Baker (Center Valley, PA, USA), respectively.

\section{3 | Tissue preparation}

A control mouse lung tissue was embedded in gelatin $(100 \mathrm{mg} / \mathrm{mL}$ aqueous) and placed into a $-80^{\circ} \mathrm{C}$ freezer. ${ }^{10}$ Holes were drilled into the frozen gelatin using a RotaCraft RC12VS mini rotary tool kit (Shesto Ltd, London, UK) fitted with a $3 \mathrm{~mm}$ diameter drill bit. The holes were then filled with control rat lung homogenate, which was prepared by adding $500 \mathrm{mg}$ of tissue to a $2-\mathrm{mL}$ tube that contained approximately 50 glass beads. The tube was then shaken at $4800 \mathrm{rpm}$ for $3 \times 60$ s using a mini-beadbeater (Biospec Products, Bartlesville, OK, USA). Then $200 \mu \mathrm{L}$ of water was added to enable the homogenate to be pipetted into the holes in the gelatin block, which was stored on dry ice to immediately freeze the homogenate. These act as registration markers for later image reconstruction. ${ }^{12}$ The 
embedded tissue was then sectioned at a temperature of $-20^{\circ} \mathrm{C}$ using a cryostat (Leica, Wetzlar, Germany) to obtain $12 \mu \mathrm{m}$ sections at $120 \mu$ $\mathrm{m}$ intervals, which were thaw mounted onto glass slides (Figure S1, supporting information).

\section{4 | Matrix application}

The mice lung tissue sections were coated with $5 \mathrm{mg} / \mathrm{mL}$ CHCA in 70:30 $\mathrm{MeOH}$. $\mathrm{H}_{2} \mathrm{O}$ with $0.2 \%$ TFA was then applied using a Suncollect automated pneumatic sprayer (Sunchrom, Friedrichsdorf, Germany) in a series of layers. The initial seeding layer was applied at $2 \mu \mathrm{L} / \mathrm{min}$ and subsequent layers were added at $3 \mu \mathrm{L} / \mathrm{min}$. The rat lung tissue sections were coated with $7 \mathrm{mg} / \mathrm{mL} \mathrm{NOR}$ in $2: 1 \mathrm{CHCl}_{3} / \mathrm{MeOH}$ using a TM-sprayer (HTX Technologies, Carrboro, NC, USA). The following settings were used: temperature $30^{\circ} \mathrm{C}$, flow rate 0.120 $\mathrm{mL} / \mathrm{min}$, velocity $1200 \mathrm{~mm} / \mathrm{min}$.

\section{5 | Instrumentation}

Mass spectra and imaging data of mouse lung tissue were acquired in positive ion mode on an Applied Biosystems/MDS Sciex hybrid quadrupole time-of-flight mass spectrometer (Q-Star Pulsar-i) with an orthogonal MALDI source (Applied Biosystems, Foster City, CA, USA) and using a high repetition neodymium-doped yttrium vanadate ( $\mathrm{Nd}$ : $\mathrm{YVO}_{4}$ ) laser (5 kHz) (Elforlight Ltd, Daventry, UK). Image acquisition was performed at a spatial resolution of $150 \mu \mathrm{m} \times 150 \mu \mathrm{m}$ in "Raster Image" mode; images were generated using the freely available Novartis Biomap 3.7.5.5 software (www.maldi-msi.org).

Analysis of rat lung tissue was performed using a rapifleX MALDI Tissuetyper system (Bruker Daltonik $\mathrm{GmbH}$, Bremen, Germany) equipped with a Nd:YAG laser $(10 \mathrm{kHz})$. The instrument was operated in reflectron mode in the mass range of $m / z \quad 400-1000$. The instrument was calibrated prior to analysis using red phosphorus clusters. ${ }^{17}$ The laser power was $80 \%$ with an accumulation of 100 shots. Images of the whole tissue sections were acquired using a $50 \times 50 \mu \mathrm{m}$ raster $(25 \times 25 \mu \mathrm{m}$ beam scan area). The images were generated using Flexlmaging version 5.0 software (Bruker Daltonik $\mathrm{GmbH})$.

Confirmation analysis in the form of tandem mass spectrometry (MS/MS) measurements was performed on a MALDI HDMS Synapt G2-Si mass spectrometer (Waters Corp., Wilmslow, UK) equipped with a Nd:YAG laser $(1 \mathrm{kHz})$. The laser power was 200 arbitrary units and the ions of interest were fragmented by collision-induced dissociation (CID) in the trap cell with an isolation window of approximately $3 \mathrm{Da}$ (defined by the quadrupole low and high mass resolution in the instrument control software). High mass resolution measurements $(100,000$ at $\mathrm{m} / \mathrm{z} 500)$ were performed using a solariX Fourier transform ion cyclotron resonance (FTICR) mass spectrometer (Bruker Daltonik $\mathrm{GmbH}$ ) equipped with a $9.4 \mathrm{~T}$ superconducting magnet and $\mathrm{Nd}$ :YAG laser $(2 \mathrm{kHz})$. The instrument was operated in positive ion mode in the mass range $m / z$ 100-1000.

\section{$2.6 \quad$ Data processing}

Images of selected masses generated in BioMap 3.8.0.4 software (https://ms-imaging.org/wp/biomap/) were exported in the JPEG format (File $\rightarrow$ Export $\rightarrow$ Image). Images of selected masses generated in FlexImaging 5.0 software were copied to the clipboard. Using Microsoft PowerPoint (or available image processing software) the images were aligned using the fiducial markers as a guide; the images were cropped to ensure that they were all the same size, and saved in the JPEG format.

Using Image J 1.46r software (http://rsbweb.nih.gov/ij/), the individual images of the airway or parenchyma were opened in order and stacked together (Image $\rightarrow$ Stacks $\rightarrow$ Images to Stack). For visualization and presentation purposes, two of each image were opened to double the number of sections. The stacks were then saved in the TIFF format. Once the image stacks had been generated, they were converted into a 3D model that could be freely manipulated (Plugins $\rightarrow 3 D \rightarrow 3 D$ viewer). In the 3D viewer, a second stack was added (File $\rightarrow$ Add content $\rightarrow$ from file). The transparency of the parenchyma was adjusted in order to provide a better view of the airways. To do this, the parenchyma stack was selected (Select $\rightarrow$ check the tick box for the parenchyma stack) and the transparency was adjusted to the desired value (Edit $\rightarrow$ attributes $\rightarrow$ change transparency). Movies showing $360^{\circ}$ views of the two 3D models were recorded in the 3D viewer window (View $\rightarrow$ Record 360 deg rotation). These movies are supplied as supporting information.

Mass spectral post-processing and recalibration were performed using mMass software. ${ }^{18}$

\subsection{Histological staining}

Hematoxylin and eosin (H\&E) staining was performed on a rat lung tissue section post imaging. Following analysis, the tissue section was immersed in $100 \% \mathrm{MeOH}$ for $30 \mathrm{~s}$ to remove the matrix. The sample was then washed with a series of solutions $(1 \times 100 \% \mathrm{EtOH}, 2 \times 95 \%$ $\mathrm{EtOH}, 2 \times 70 \% \mathrm{EtOH}$ and deionised water for $2 \mathrm{~min}$ each). The sample was then stained with hematoxylin for $3 \mathrm{~min}$ and subsequently washed with running tap water for $3 \mathrm{~min}$. The tissue section was then stained with eosin for $30 \mathrm{~s}$ and washed again with running tap water for $3 \mathrm{~min}$. After being stained the sample was placed into 100\% $\mathrm{EtOH}$ for $1 \mathrm{~min}$; following this the tissue section was placed in xylene for 30 s. After the samples had been dried at room temperature, glass coverslips were placed onto the stained tissue section using Entellen mounting medium. An Aperio CS2 image capture device (Leica Biosystems Imaging, Vista, CA, USA) was then used to acquire images of the stained tissue section.

\section{3 | RESULTS AND DISCUSSION}

One of the challenges of $3 \mathrm{D}$ MALDI-MSI is that it requires the preparation of high-quality tissue sections. The frozen tissue sample is 
sliced into serial sections, and tissue tearing, rolled-up edges and deformations can make the correlation of consecutive images difficult. ${ }^{19}$ The preparation of lung tissue sections is challenging due to fragile parenchyma, often resulting in badly damaged tissue sections. In order to overcome this, lung tissue is often inflated with embedding media in order to produce high-quality tissue sections for MALDI-MSI. ${ }^{20}$ Gelatin was chosen to externally embed the control mouse lung tissue because it preserves the integrity and morphology of the tissue. Gelatin provides less mass spectral interference than the optimal cutting temperature (OCT) embedding media usually used for cryosectioning. ${ }^{10,21}$

Once the embedding and sectioning method had been optimized, the next step was to obtain the molecular profiles of the tissue sections and registration markers. The MALDI-MS spectra obtained from the control mouse lung tissue and registration markers are shown in Figure 1.

A region of interest was drawn on the control mouse lung tissue and on one of the registration markers; the corresponding peak list was exported in text format and imported into the freely available mMass software. ${ }^{18}$ The mass spectra (obtained from the two regions) were displayed in pairs by flipping one of the spectra, as shown in Figure 2. In both regions there is an abundance of possible lipid fragments such as choline at $\mathrm{m} / \mathrm{z}$ 104.07, lysophosphatidylcholine (LPC) at $\mathrm{m} / \mathrm{z} 496.33$ and phosphocholine at $\mathrm{m} / \mathrm{z} 184.08$, which is the most abundant peak in both regions. The MALDI-MS spectra also show the presence of possible intact phospholipids in the range of $\mathrm{m} / \mathrm{z} 700-800$; the most abundant species in this region at $\mathrm{m} / \mathrm{z} 734.55$ and 756.56 were tentatively identified as phosphatidylcholines (PCs). In order to confirm the identity of the lipids, MS/MS and accurate mass measurements were performed. Annotated MS/MS spectra of the selected endogenous species are shown in Figures S2A-S2I (supporting information). High mass resolution accurate mass measurements were also performed to further confirm the molecular identities; these data are shown in Table S1 (supporting informatio). The MS/MS spectra were compared with those in the literature and in databases such as lipid maps (www.lipidmaps.org) or the ALEX123 lipid calculator (www.alex123.info). ${ }^{22}$

Proper lipid identification is important in order to better understand the changes in lipid expression associated with different diseases; however, this is challenging due to the complex nature of biological tissues. Measurements performed with high-resolution mass spectrometers, such as FTICR instruments, can provide better mass accuracy $(\sim 1 \mathrm{ppm})$, which can then generate an elemental formula that enables more accurate lipid database searches. However, these measurements can only provide the sum composition of the fatty acid chains and cannot differentiate between isomers.

In order to provide more information, MS/MS measurements are performed. The most abundant information gathered from

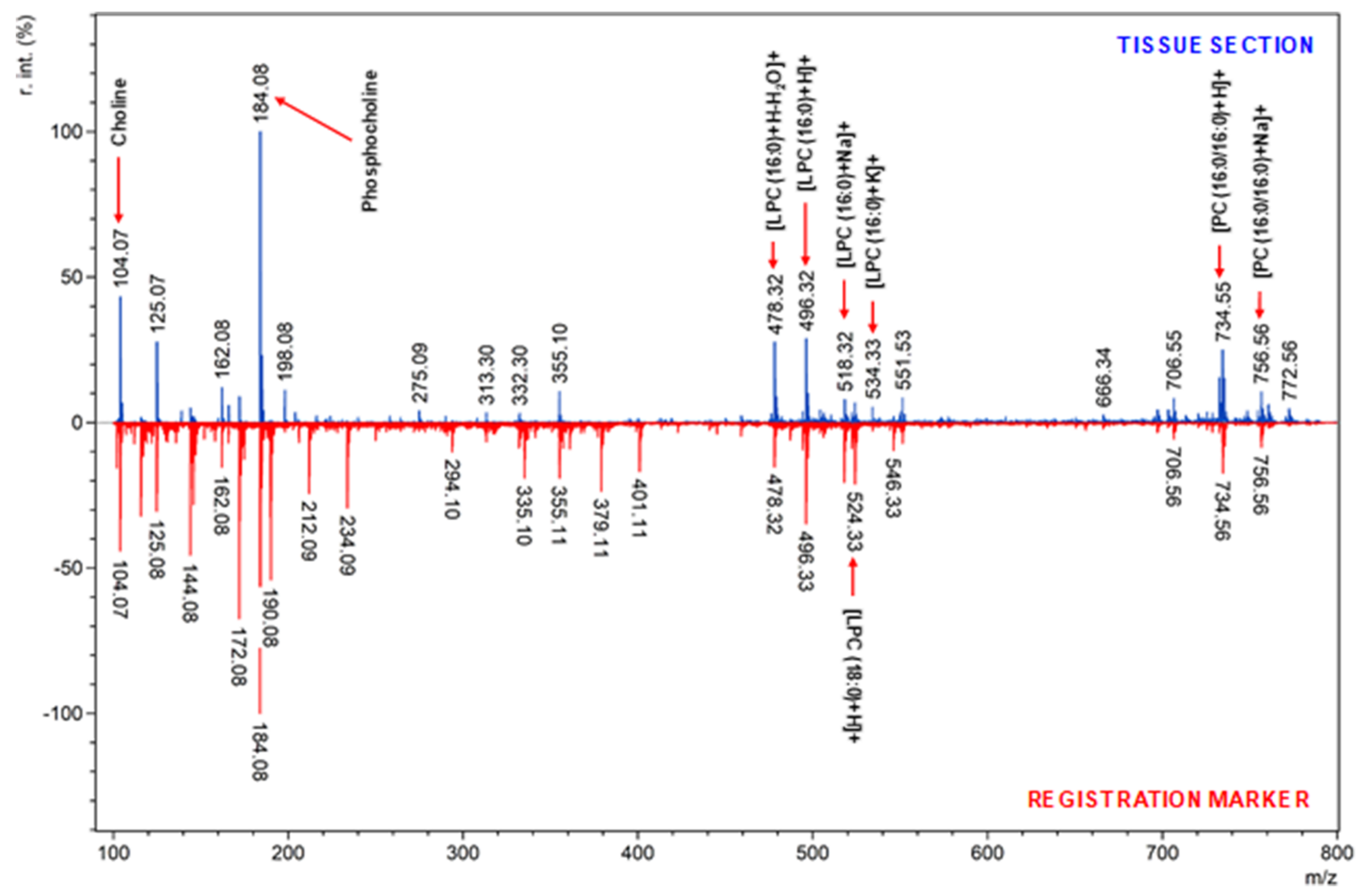

FIGURE 1 MALDI-MS spectra obtained from the control mouse lung tissue (blue spectrum) and the registration markers (red spectrum). The annotated peaks were confirmed using MS/MS and high mass resolution measurements and later visualized [Color figure can be viewed at wileyonlinelibrary.com] 

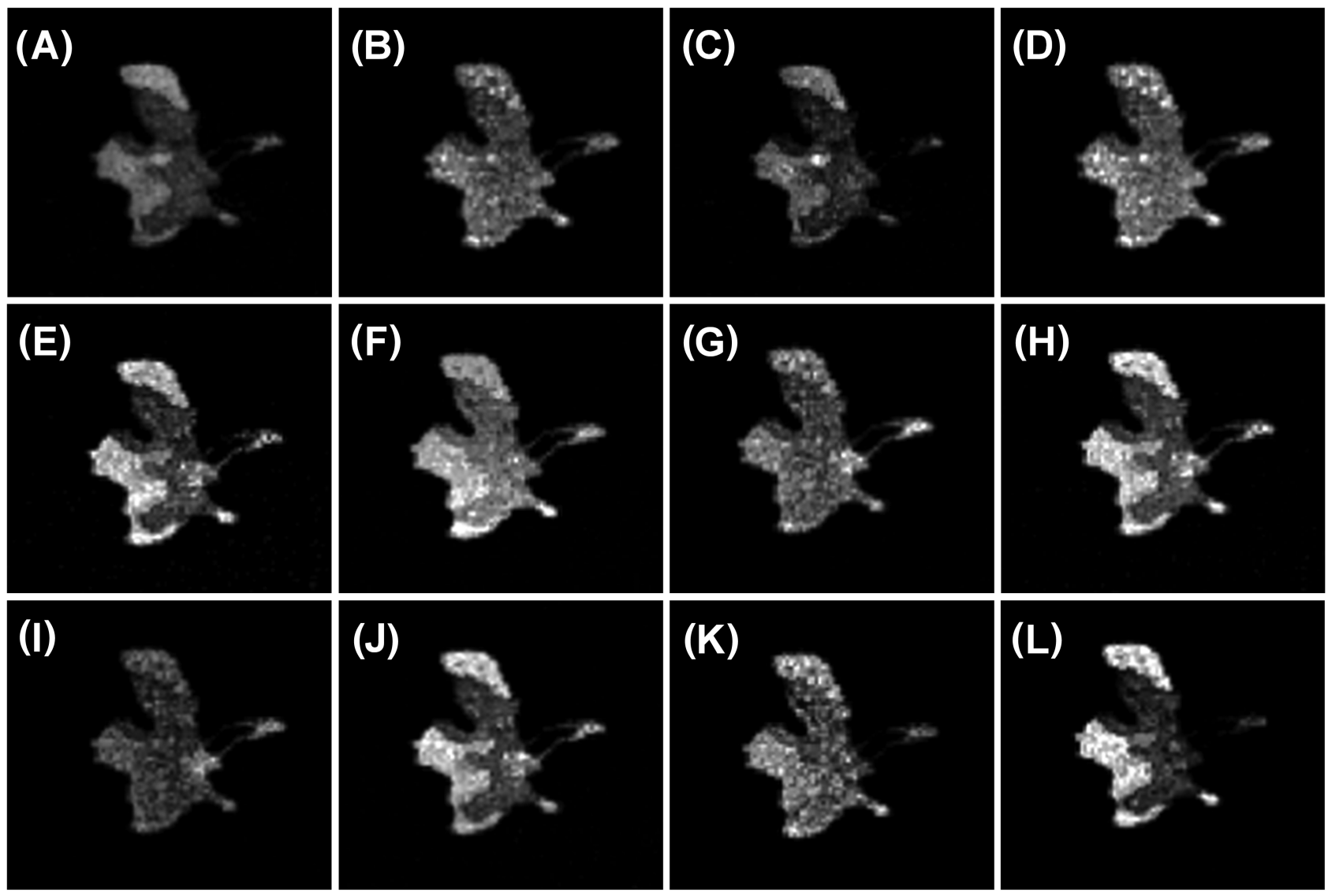

\section{$10 \mathrm{~mm}$}

FIGURE 2 MALDI-MS images showing the distribution of various endogenous species in the control mouse lung tissue section. A, Choline at $\mathrm{m} / \mathrm{z}$ 104.07; B, phosphocholine fragment at $\mathrm{m} / \mathrm{z}$ 124.9; C, phosphocholine fragment at $\mathrm{m} / \mathrm{z}$ 162.1; D, phosphocholine at $\mathrm{m} / \mathrm{z}$ 184.08; E, [LPA $(18: 1)+\mathrm{Na}]^{+}$at $\mathrm{m} / \mathrm{z}$ 459.32; F, [LPC (16:0) $\left.+\mathrm{H}-\mathrm{H}_{2} \mathrm{O}\right]^{+}$at $\mathrm{m} / \mathrm{z}$ 478.32; G, [LPC (16:0) + H] ${ }^{+}$at $\mathrm{m} / \mathrm{z}$ 496.32; H, [LPC (16:0) $\left.+\mathrm{Na}\right]^{+}$at $\mathrm{m} / \mathrm{z}$ 518.32; I,

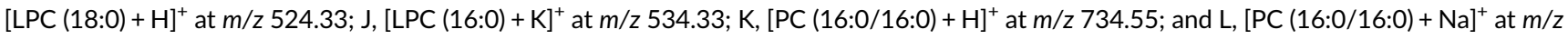
756.56. Spatial resolution $150 \times 150 \mu \mathrm{m}$, normalized with protonated CHCA matrix peak at $\mathrm{m} / \mathrm{z} 190.05$

MS/MS measurements in positive ion mode is related to the headgroup of the lipids. In the case of phospholipids, the most common peak observed is that of phosphocholine at $m / z 184$. However, other information can confirm if the lipid is protonated, sodiated or potassiated by monitoring peaks related to the headgroup cyclic 1,2-phosphodiester of phospholipids at $\mathrm{m} / \mathrm{z}$ 125,147 or 163 , respectively. ${ }^{23,24}$ Other peaks at $m / z 60,86$ and 104 representing trimethylamine, dehydrated choline and choline, respectively, are also related to the phospholipid headgroup but are present regardless of the ion type. Corresponding peaks related to the neutral loss of trimethylamine $(59 \mathrm{Da})$, the phosphocholine headgroup (183 Da) and sodiated or potassiated phosphocholine (205 and $221 \mathrm{Da}$, respectively) are also observed (Figures S2F, S2G and $\mathrm{S} 2 \mathrm{H}$, supporting information).

MS/MS measurements can also determine the identity of the two fatty acid chains present in the lipid molecule, as was demonstrated with the peak at $\mathrm{m} / \mathrm{z} 734.54$ (Figure S2F, supporting information). Two product ion peaks at $\mathrm{m} / \mathrm{z} 478.31$ and 496.31 were observed, which corresponds to the neutral loss of palmitic acid or 16:0 (256 Da) and the corresponding ketene (238 Da). As only two peaks were observed, it was determined that this was the phosphatidylcholine [PC $(16: 0 / 16: 0)+H]^{+}$. However, in the case of lipids with different fatty acid chains, the position of the fatty acid chains (termed $s n-1$ and $s n-2$ ) and the position of the double bonds cannot be determined with high-resolution or MS/MS measurements. Using techniques such as ozone-induced dissociation (OzID) coupled with mass spectrometry imaging, it is now possible to obtain this information. It has also been demonstrated that isomeric lipid species have distinct distributions in biological tissues. ${ }^{25,26}$ Following profiling, MALDI-MSI was performed on a consecutive tissue section (adjacent tissue sections collected between those used in the $3 \mathrm{D}$ model) in order to determine the distribution of the observed molecular species. The MALDI-MS images of selected ions related to molecular species are displayed in Figure 2. 


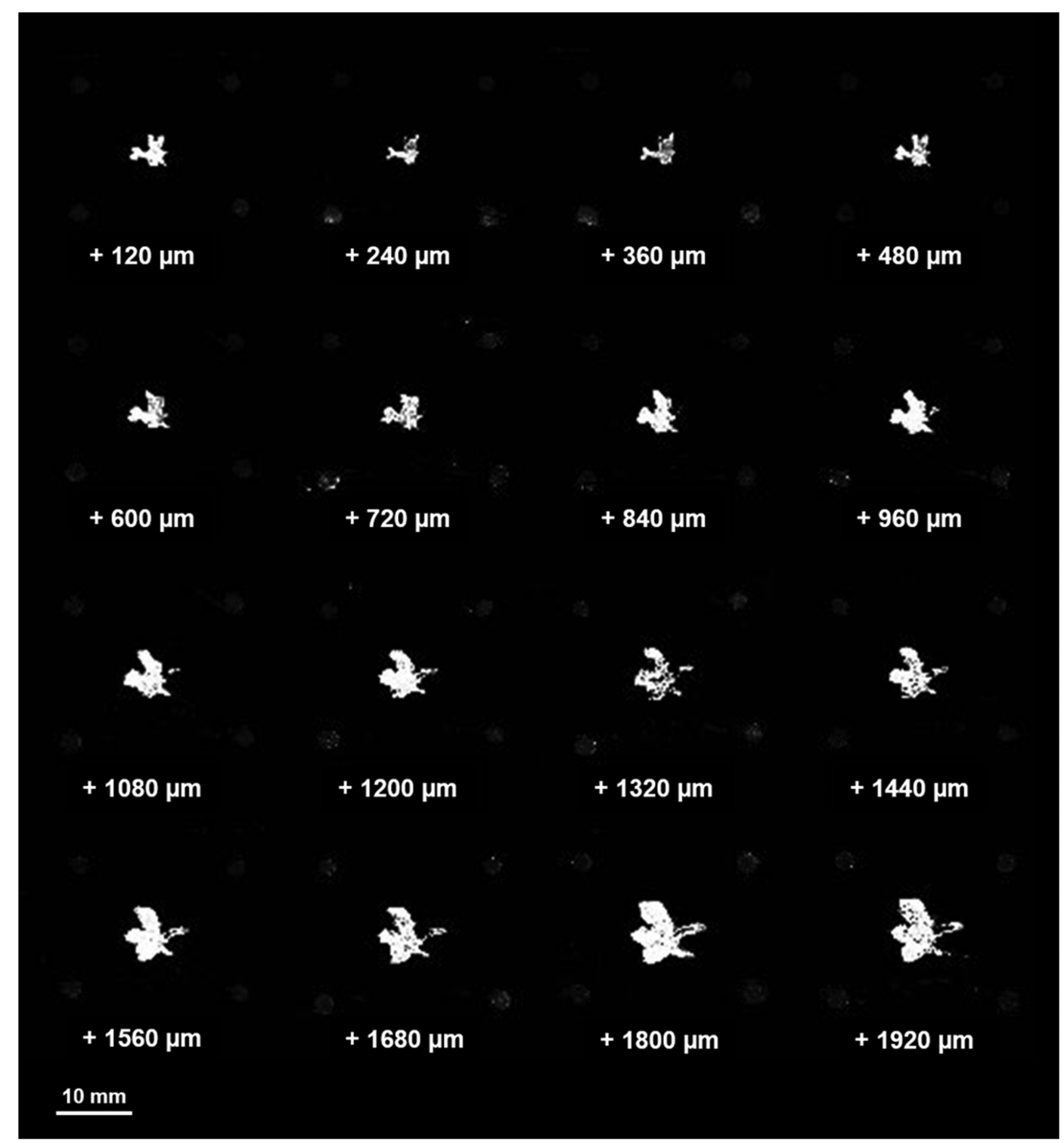

FIGURE 3 2D MALDI-MS images showing the distribution of phosphocholine at $\mathrm{m} / \mathrm{z} 184.08$ following normalization against the protonated CHCA matrix at $m / z$ 190.05, throughout the 16 control mouse lung tissue sections
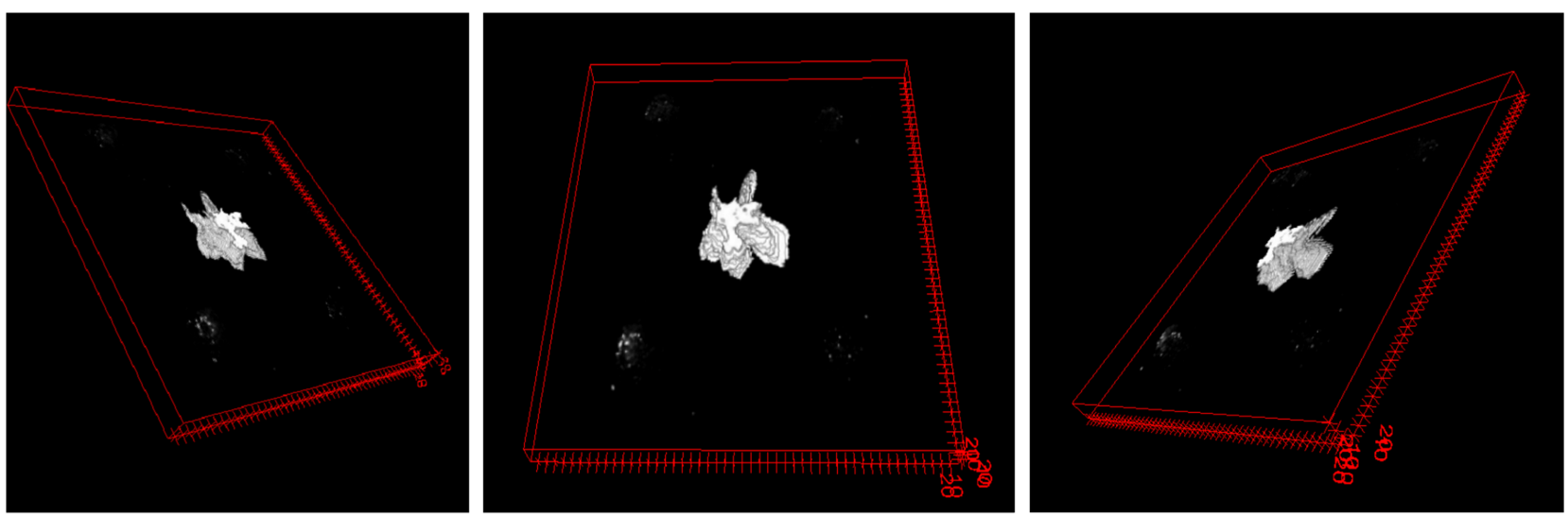

FIGURE 4 3D MALDI-MS images produced using Image J software showing the distribution of phosphocholine at $\mathrm{m} / \mathrm{z} 184.08$ following normalization against the protonated CHCA matrix at $\mathrm{m} / \mathrm{z}$ 190.05, throughout the control mouse lung tissue from different angles 

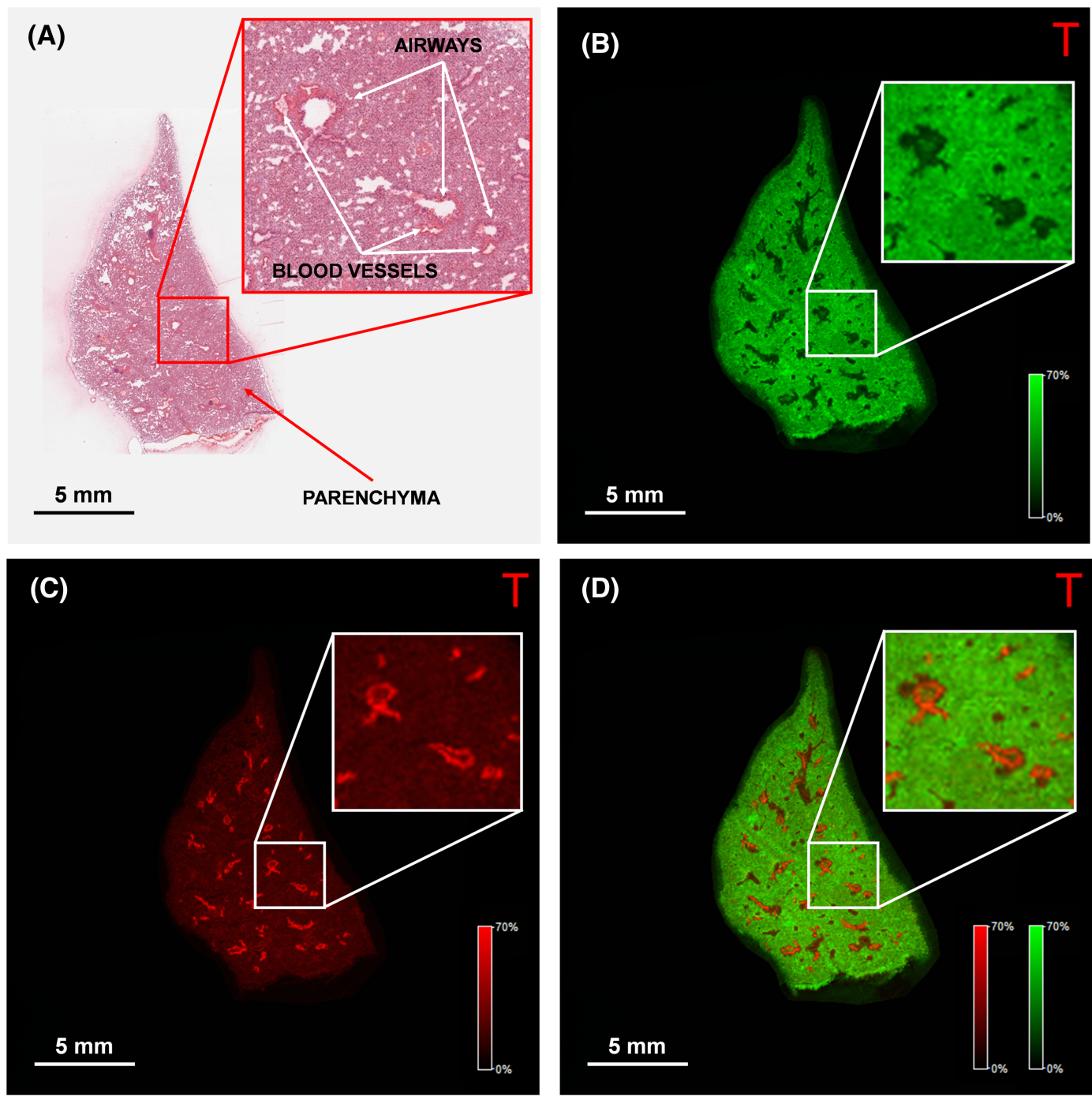

FIGURE 5 Correlation of molecular markers with histological staining. A, Hematoxylin and eosin (H\&E) staining of lung tissue post imaging. MALDI-MS images showing the distribution of B, parenchyma marker ([PC (32:1) $\left.+\mathrm{K}]^{+}\right)$at $\mathrm{m} / \mathrm{z} 770.51 ; \mathrm{C}$, airway marker $\left([\mathrm{PC}(36: 4)+\mathrm{K}]^{+}\right)$at $m / z$ 820.52; and D, overlay of selected molecular markers. Spatial resolution $50 \times 50 \mu \mathrm{m}$, normalized with TIC as indicated by the red 'T' in the top right corner based on reporting nomenclature ${ }^{28}$

The MALDI-MS images (Figure 2) show the distribution of various endogenous species throughout the control mouse lung tissue. From these data it can be seen that choline at $\mathrm{m} / \mathrm{z} 104.07$ (Figure $2 \mathrm{~A}$ ) is localized in specific regions of the tissue section while phosphocholine at $\mathrm{m} / \mathrm{z} 184.08$ (Figure 2D) is distributed throughout the control mouse lung tissue section. Other species included LPCrelated ions such as $\left[\mathrm{LPC}(16: 0)+\mathrm{H}-\mathrm{H}_{2} \mathrm{O}\right]^{+}$at $\mathrm{m} / \mathrm{z} 478.32$ (Figure 2F), [LPC $(16: 0)+\mathrm{H}]^{+}$at $\mathrm{m} / \mathrm{z} 496.33$ (Figure 2G), as well as the sodium and potassium adducts at $\mathrm{m} / \mathrm{z} 518.33$ and 543.33 (Figures $2 \mathrm{H}$ and $2 \mathrm{~J}$, respectively). The ions at $\mathrm{m} / \mathrm{z} 734.55$ and 756.56 were identified as $[\mathrm{PC}(32: 0)+\mathrm{H}]^{+}$and its sodium adduct $[\mathrm{PC}(32: 0)+\mathrm{Na}]^{+}$(Figures $2 \mathrm{~K}$ and $2 \mathrm{~L}$, respectively). These species have been previously shown to be molecular markers for the parenchyma of the lung. ${ }^{27}$ The images obtained show that these species are also widespread throughout the lung tissue sections.
Interestingly, the distribution of the selected molecular species appears to be influenced by the type of ion (protonated or cationized molecule). This is observed in the images of protonated species (Figures 2B, 2D, 2F, 2G, 2I and 2K), which appear to be homogenously distributed throughout the lung tissue section. In contrast, sodiated and potassiated species (Figures $2 \mathrm{~A}, 2 \mathrm{C}, 2 \mathrm{E}, 2 \mathrm{H}$, $2 \mathrm{~J}$ and $2 \mathrm{~K}$ ) are more localized in the parenchyma. All the selected species were also observed in each of the homogenate registration markers located in the four corners of the images.

The generation of a 3D image was performed by serially sectioning the mouse lung tissue with defined and measured spatial intervals (z-dimension). A total of 16 sections were collected and analyzed by MALDI-MSI. Phosphocholine at $\mathrm{m} / \mathrm{z}$ 184.08, which was the most abundant lipid species, was chosen to show the structure of the lung tissue. The resulting 2D MALDI-MS images of the 16 images 


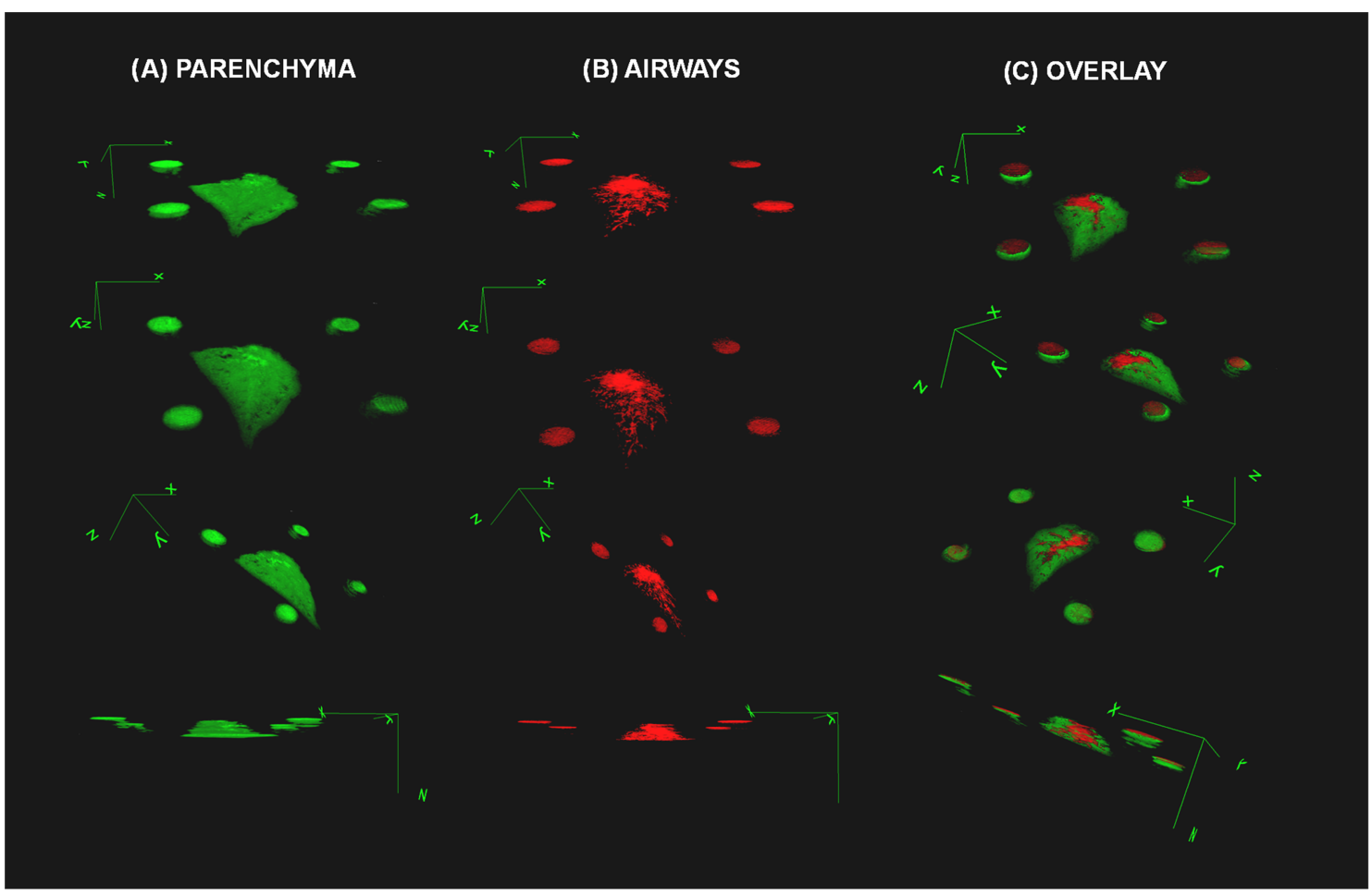

FIGURE 6 3D MALDI-MS images of the parenchyma and airways showing the distribution of $A$, $[P C(32: 1)+K]^{+}$at $m / z 770.51$ that highlights the parenchyma and $\mathrm{B},[\mathrm{PC}(36: 4)+\mathrm{K}]^{+}$at $\mathrm{m} / \mathrm{z} 820.52$ that highlights the airways. C, Overlay of the parenchyma and airway 3D models (transparency of the parenchyma stack set to $12 \%$ )

generated showing the distribution of phosphocholine in the control mouse lung tissue are presented in Figure 3.

The $3 \mathrm{D}$ reconstruction of the distribution of phosphocholine at $\mathrm{m} / \mathrm{z} 184.08$ generated using the Image J software is shown in Figure 4 and is displayed from different angles. The images show that phosphocholine is widely distributed and only shows the external structure of the control mouse lungs; however, the images clearly display the trachea and the right and left lobes.

Following the evaluation of the method, the left lung of a rat was prepared in the same manner as the previous sample and cut into 24 sections. Upon analysis two species that defined the parenchyma and airways were detected, which were identified as $[\mathrm{PC}(32: 1)+\mathrm{K}]^{+}$at $\mathrm{m} / \mathrm{z} 770.51$ and $[\mathrm{PC}(36: 4)+\mathrm{K}]^{+}$at $\mathrm{m} / \mathrm{z}$ 820.52, respectively. The individual images of the two species are shown in Figures S3 and S4 (supporting information), respectively, and the localization of these species in relation to histological features is presented in Figure 5. The H\&E stain of the last tissue section in the stack post imaging (Figure 5A) shows the presence of the airways with blood vessels in close proximity, which are surrounded by the parenchyma. The MALDI-MS image of the parenchyma marker (Figure 5B) shows that this is homogenously distributed but is absent from the airways and blood vessels. In contrast, the airway marker (Figure $5 \mathrm{C}$ ) is located in the parenchyma but is elevated in the airway walls. The overlay (Figure 5D) clearly demonstrates the complementarity of these two species.
Previously identified species related to both the airways and the parenchyma were also present in the data sets but were not used for the construction of the 3D models. ${ }^{27}$ The 3D MALDI-MS images (Figure 6) were constructed following alignment, and are viewed from different angles. The image of the parenchyma (Figure 6A) defines the shape of the lung, and the image of the airways (Figure 6B) shows the presence of the large airways that further divide into smaller airways towards the periphery of the lungs. The overlay of the two 3D models (Figure 6C) shows the airways embedded within the parenchyma and further demonstrates how complementary the selected endogenous species are (see videos 1-3 in the supporting information). Both species were also present in the fiducial markers around the tissue; however, as observed in Figures S2 and S3 (supporting information), the fiducial markers are absent in later sections. This is due to air bubbles that can form when adding the homogenate into the drilled holes, which when frozen results in broken or missing fiducial markers. Should this happen the individual images can be aligned using the optical image as a guide.

\section{4 | CONCLUSIONS}

The work presented here describes a method for monitoring the three-dimensional distribution of endogenous species in the lungs of a mouse. Control mouse lung tissue was serially sectioned resulting in 
16 tissue sections obtained at defined intervals; these sections were individually analyzed. Later, another 3D model was constructed using a control rat lung, which was prepared in the same manner. Here two molecular markers, identified as $\left([\mathrm{PC}(32: 1)+\mathrm{K}]^{+}\right)$and $([\mathrm{PC}(36: 4)+$ $\mathrm{K}^{+}$) that defined the parenchyma and airways, respectively, were used. The addition of registration markers enabled straightforward image alignment. Then utilizing Image J software the individual MALDI-MS images which showed the distribution of a specific endogenous species were stacked together and viewed as a 3D image.

Whilst the serial-sectioning method requires careful sample preparation and is time consuming, the methodology could potentially be used to monitor the distribution of inhaled drug formulas in the lungs or endogenous species associated with respiratory diseases. Quantitation of compounds in individual tissue sections could be performed using previously reported methods. ${ }^{29}$

\section{ACKNOWLEDGEMENTS}

This work was supported by a Medical Research Council CASE studentship from GlaxoSmithKline.

\section{PEER REVIEW}

The peer review history for this article is available at https://publons. com/publon/10.1002/rcm.8957.

\section{ORCID}

Ron M.A. Heeren (D) https://orcid.org/0000-0002-6533-7179

Malcolm R. Clench (D) https://orcid.org/0000-0002-0798-831X

\section{REFERENCES}

1. Sakas G. Trends in medical imaging: From 2D to 3D. Comput Graph. 2002;26(4):577-587.

2. Antoch G, Bockisch A. Combined PET/MRI: A new dimension in whole-body oncology imaging? Eur J Nucl Med Mol Imaging. 2009;36 (1):113-120

3. Fletcher JS, Rabbani S, Henderson A, Lockyer NP, Vickerman JC. Three-dimensional mass spectral imaging of HeLa-M cells - sample preparation, data interpretation and visualisation. Rapid Commun Mass Spectrom. 2011;25(7):925-932.

4. Nemes $P$, Barton AA, Vertes A. Three-dimensional imaging of metabolites in tissues under ambient conditions by laser ablation electrospray ionization mass spectrometry. Anal Chem. 2009;81(16): 6668-6675.

5. Crecelius AC, Cornett DS, Caprioli RM, Williams B, Dawant BM, Bodenheimer B. Three-dimensional visualization of protein expression in mouse brain structures using imaging mass spectrometry. J Am Soc Mass Spectrom. 2005;16(7):1093-1099.

6. Andersson M, Groseclose MR, Deutch AY, Caprioli RM. Imaging mass spectrometry of proteins and peptides: 3D volume reconstruction. Nat Methods. 2008;5(1):101-108.

7. Sinha TK, Khatib-Shahidi S, Yankeelov TE, et al. Integrating spatially resolved three-dimensional MALDI IMS with in vivo magnetic resonance imaging. Nat Methods. 2008;5(1):57-59.

8. Mallah K, Quanico J, Trede D, et al. Lipid changes associated with traumatic brain injury revealed by 3D MALDI-MSI. Anal Chem. 2018; 90(17):10568-10576.
9. Paine MRL, Liu J, Huang D, et al. Three-dimensional mass spectrometry imaging identifies lipid markers of Medulloblastoma metastasis. Sci Rep. 2019;9(1):2205-2205.

10. Chen R, Hui L, Sturm RM, Li L. Three dimensional mapping of neuropeptides and lipids in crustacean brain by mass spectral imaging. J Am Soc Mass Spectrom. 2009;20(6):1068-1077.

11. Eberlin LS, Ifa DR, Wu C, Cooks RG. Three-dimensional vizualization of mouse brain by lipid analysis using ambient ionization mass spectrometry. Angew Chem Int Ed. 2010;49(5):873-876.

12. Chughtai K, Jiang L, Greenwood TR, et al. Fiducial markers for combined 3-dimensional mass spectrometric and optical tissue imaging. Anal Chem. 2012;84(4):1817-1823.

13. Vos DRN, Jansen I, Lucas $M$, et al. Strategies for managing multipatient 3D mass spectrometry imaging data. J Proteomics. 2019;193: 184-191.

14. Giordano S, Morosi L, Veglianese $\mathrm{P}$, et al. 3D mass spectrometry imaging reveals a very heterogeneous drug distribution in tumors. Sci Rep. 2016;6(1):37027.

15. Ogrinc Potocnik N, Porta T, Becker M, Heeren RM, Ellis SR. Use of advantageous, volatile matrices enabled by next-generation highspeed matrix-assisted laser desorption/ionization time-of-flight imaging employing a scanning laser beam. Rapid Commun Mass Spectrom. 2015;29(23):2195-2203.

16. Trede D, Schiffler S, Becker M, et al. Exploring three-dimensional matrix-assisted laser desorption/ionization imaging mass spectrometry data: Three-dimensional spatial segmentation of mouse kidney. Anal Chem. 2012;84(14):6079-6087.

17. Sládková K, Houška J, Havel J. Laser desorption ionization of red phosphorus clusters and their use for mass calibration in time-offlight mass spectrometry. Rapid Commun Mass Spectrom. 2009;23 (19):3114-3118.

18. Strohalm M, Kavan D, Novak P, Volny M, Havlicek V. mMass 3: A cross-platform software environment for precise analysis of mass spectrometric data. Anal Chem. 2010;82(11):4648-4651.

19. Chughtai K, Heeren RM. Mass spectrometric imaging for biomedical tissue analysis. Chem Rev. 2010;110(5):3237-3277.

20. Carter CL, Jones JW, Farese AM, MacVittie TJ, Kane MA. Inflationfixation method for lipidomic mapping of lung biopsies by matrix assisted laser desorption/ionization-mass spectrometry imaging. Anal Chem. 2016;88(9):4788-4794.

21. Schwartz SA, Reyzer ML, Caprioli RM. Direct tissue analysis using matrix-assisted laser desorption/ionization mass spectrometry: Practical aspects of sample preparation. J Mass Spectrom. 2003;38(7): 699-708.

22. Pauling JK, Hermansson M, Hartler J, et al. Proposal for a common nomenclature for fragment ions in mass spectra of lipids. PloS One. 2017;12(11):e0188394

23. Murphy RC, Hankin JA, Barkley RM. Imaging of lipid species by MALDI mass spectrometry. J Lipid Res. 2009;50(Suppl (Suppl)):S317S322.

24. Berry KA, Hankin JA, Barkley RM, Spraggins JM, Caprioli RM, Murphy RC. MALDI imaging of lipid biochemistry in tissues by mass spectrometry. Chem Rev. 2011;111(10):6491-6512.

25. Ellis SR, Hughes JR, Mitchell TW, In het Panhuis M, Blanksby SJ. Using ambient ozone for assignment of double bond position in unsaturated lipids. Analyst. 2012;137(5):1100-1110.

26. Paine MRL, Poad BLJ, Eijkel GB, et al. Mass spectrometry imaging with isomeric resolution enabled by ozone-induced dissociation. Angew Chem Int Ed. 2018;57(33):10530-10534.

27. Berry KA, Li B, Reynolds SD, et al. MALDI imaging MS of phospholipids in the mouse lung. J Lipid Res. 2011;52(8):1551-1560.

28. McDonnell LA, Römpp A, Balluff B, et al. Discussion point: Reporting guidelines for mass spectrometry imaging. Anal Bioanal Chem. 2015; 407(8):2035-2045. 
29. Russo C, Brickelbank N, Duckett C, Mellor S, Rumbelow S, Clench MR. Quantitative investigation of terbinafine hydrochloride absorption into a living skin equivalent model by MALDI-MSI. Anal Chem. 2018;90(16):10031-10038.

\section{SUPPORTING INFORMATION}

Additional supporting information may be found online in the Supporting Information section at the end of this article.
How to cite this article: Flinders B, Morrell J, Marshall PS,

Ranshaw LE, Heeren RMA, Clench MR. Monitoring the threedimensional distribution of endogenous species in the lungs by matrix-assisted laser desorption/ionization mass spectrometry imaging. Rapid Commun Mass Spectrom. 2021;35:e8957. https://doi.org/10.1002/rcm.8957 